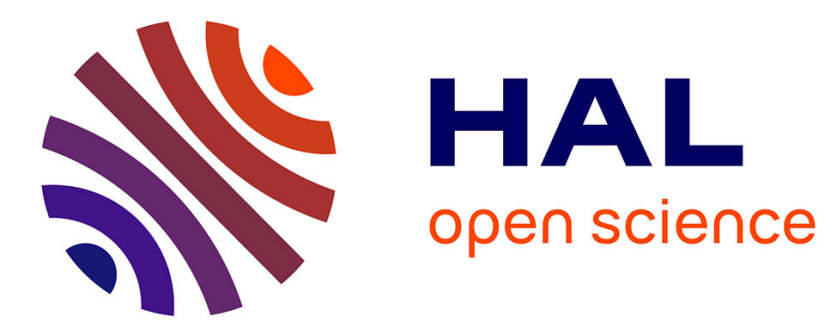

\title{
Amino Acid-Functionalized Polyelectrolyte Films as Bioactive Surfaces for Cell Adhesion
}

\author{
M. Leal, X. Briones, V. Villalobos, Y. Queneau, A. Leiva, H. Ríos, J. Pavez, \\ C. Silva, C. Carrasco, Andrónico Neira-Carrillo, et al.
}

\section{- To cite this version:}

M. Leal, X. Briones, V. Villalobos, Y. Queneau, A. Leiva, et al.. Amino Acid-Functionalized Polyelectrolyte Films as Bioactive Surfaces for Cell Adhesion. ACS Applied Materials \& Interfaces, 2019, 11 (22), pp.19751-19762. 10.1021/acsami.9b02503 . hal-02193160

\section{HAL Id: hal-02193160 \\ https://hal-udl.archives-ouvertes.fr/hal-02193160}

Submitted on 21 Jul 2020

HAL is a multi-disciplinary open access archive for the deposit and dissemination of scientific research documents, whether they are published or not. The documents may come from teaching and research institutions in France or abroad, or from public or private research centers.
L'archive ouverte pluridisciplinaire HAL, est destinée au dépôt et à la diffusion de documents scientifiques de niveau recherche, publiés ou non, émanant des établissements d'enseignement et de recherche français ou étrangers, des laboratoires publics ou privés. 


\section{Amino Acid Functionalized Polyelectrolyte Films as Bioactive Surfaces for Cell Adhesion}

M.S. Leal, ${ }^{\dagger}$ X. Briones, ${ }^{\dagger}$ V. Villalobos, ${ }^{\dagger}$ Y. Queneau, ${ }^{\ddagger}$ A. Leiva, ${ }^{\S}$ H.E. Ríos, ${ }^{\dagger}$ A. Roth, I J.Pavez, ${ }^{\prime \prime}$ C. Silva,,$~ C$ C. Carrasco, ${ }^{l}$ Andrónico Neira-Carrillo, ${ }^{\infty}$ L. Tamayo, ${ }^{*+}$ M.D. Urzúa, ${ }^{+\dagger}$

${ }^{\dagger}$ Departamento de Química, Facultad de Ciencias, Universidad de Chile, Las Palmeras 3425, Casilla 653, Santiago, Chile

" Institut de Chimie et de Biochimie Moléculaires et Supramoléculaires, UMR 5246, CNRS; INSA-Lyon; Laboratoire de Chimie Organique, INSA-Lyon, Bât. Jules Verne, 20 Avenue Albert Einstein, Villeurbanne F-69621, France

${ }^{\S}$ Departamento Química Física, Facultad de Química, Pontificia Universidad Católica de Chile, Chile

I Departamento de Biología, Facultad de Ciencias, Universidad de Chile, P. C. 780-0023, Santiago, Chile

II Facultad de Química y Biología Universidad de Santiago de Chile, Avenida Libertador Bernardo O'Higgins 3363, Estación Central, Santiago, Chile

${ }^{\infty}$ Facultad de Ciencias Veterinarias y Pecuarias, Universidad de Chile, Av. Santa Rosa 11735, Santiago, Chile

KEYWORDS: Polyelectrolytes, amino acid functionalization, cell adhesion, SH-SY5Y neuroblastoma

ABSTRACT. Surfaces were prepared with polyelectrolyte derivatives of poly(styrene-alt-maleic anhydride) (PSMA) functionalized with amino acids of different hydropathy indices, with the aim of evaluating the effect of the chemical functionality of polyelectrolytes on SH-SY5Y neuroblastoma cell adhesion. Functionalizing PSMA derivatives with L-glutamine, L-methionine and L-tyrosine yielded PSMA-GIn, PSMA-Met and PSMA-Tyr polyelectrolytes, respectively. We first studied the adsorption behavior of PSMA functionalized with amino acids on silicon wafer surfaces modified with 3aminopropyltriethoxysilane (APS) at $\mathrm{pH} 4.0$ and 7.0 and at low and high ionic strength. The highest rate of polyelectrolyte adsorption was at $\mathrm{pH} 4.0$ and high ionic strength, and was higher with the glutamine and tyrosine films. The advance contact angles (qA) of the polyelectrolyte surfaces showed a moderate effect of ionic strength and $\mathrm{pH}$ on polyelectrolyte film wettability, with PSMA-Tyr being slightly more hydrophobic. AFM images of the polyelectrolyte surfaces showed two types of morphology: the welldefined globular nanostructure of PSMA-Met and PSMA-Tyr, and the densely packed nanofibrous-like structure of PSMA-GIn. The highest level of ionic strength caused a slight decrease in size of the nanostructure that formed the surface domains, which was reflected in the degree of surface roughness. Cell adhesion assays with polyelectrolyte film showed that SH-SY5Y neuroblastoma cells cultured on PSMA-Met present a well-extended morphology characterized by a stellate shape, with five or more actin-rich thin processes, while SH-SY5Y cells that where seeded on PSMA-GIn and PSMATyr have a round morphology, with fewer and shorter processes. These results indicate that it is possible to modulate the surface characteristics of polyelectrolyte films based on their chemical functionality and environmental parameters such as $\mathrm{pH}$ and ionic strength, in order to evaluate their effect on cell adhesion. Thus, surfaces prepared from polyelectrolytes functionalized with amino acids are an attractive and simple platform for cell adhesion, which can be used in developing biomaterials with modulated surface properties. 


\section{INTRODUCTION}

Important advances have been made in designing biomaterials for medical implants, supports for cell regeneration and biosensors for disease diagnosis, but there are still challenges to be overcome. Of particular interest are the processes and interactions that occur in the biomaterialbiological system interface, in order to achieve a favorable response of the latter (eukaryotic cell, bacterium, bone or blood). In the search for biological selectivity, it is key to understand biomaterial surface properties and how to modulate them and the responses they elicit from different cell types. Among the most important surface variables are wettability, topography, energy and surface charge. (1) It has been observed that positive surface charge and hydrophilicity enhance 3T3 fibroblast adhesion. (2) Other surface variables like roughness also play an important role, and in general some characteristics has been observed that favors the adhesion of each cell type. In the case of neuronal cell grown on silicon, surface roughness at a nanoscale of 50 to $70 \mathrm{~nm}$ favors adhesion. (3) Given the need to modulate the chemical properties of biomaterial surfaces, polyelectrolytes offer important advantages due to the variety of their chemical functionality and ionizable groups, which allows for controlling their specificity, mainly by electrostatic, dipole-dipole, hydrophobic and hydrogen bonding interactions. (4) The biological selectivity of surfaces is an important characteristic in biological applications, which can be enhanced by modifying polyelectrolytes with biomolecules like carbohydrates, amino sugars, peptides, and others. (5-7) Arginine-rich peptides have been shown to promote cellular internalization, which has led to multiple modifications of chitosan with arginine to imitate the cellular function of arginine peptides. $(8,9)$ It has been reported that modification of chitosan grafting with hydrophobic amino acids improves blood compatibility and increases cell viability. These effects are proportional to the increase in the hydrophobicity of chitosan modified with amino acids of different hydropathy indices. Studies have evaluated the osteogenic capacity of films of chitosan modified with anionic carbohydrates, and have found that the presence of 4-chondroitin sulfate (chondroitin 4-sulfate) promotes BMSC cell proliferation. (10) The modification of chitosan with integrin-binding consensus peptides common to cell matrix proteins like RGD (Arg-Gly-Asp) and GRGD (GlyArg-Gly-Asp) increases the adhesion of multiple cell types (e.g. osteosarcoma, osteoblasts and fibroblasts). (11-13) However, functionalization methods for cell adhesion peptides are expensive and often require multiple stages of conjugation. While several studies have demonstrated the advantages of modifying chitosan to promote cell interaction selectivity, chitosan has the disadvantages of low water solubility, in vivo depolymerization and hemoincompatibility. (14) The ideal polyelectrolyte would be stable over a wide $\mathrm{pH}$ range, and would require simple and inexpensive modification methods.

Polyelectrolytes like maleic anhydride derivatives have the advantage of a high degree of water solubility over a wide pH range, in addition to being biologically active. (15) The high degree of reactivity of the co-monomer maleic anhydride allows the synthesis of alternating copolymers that can be used as platforms for functional modulation, providing a high degree of chemical versatility that can be enhanced by modification with biomolecules that favor the required biological response. (16) Given the reactivity of the maleic anhydride co-monomer and the easiness of synthesizing alternating copolymers, in addition to their water solubility and excellent biocompatibility, the use of these copolymers as platforms for the covalent attachment of biomolecules would allow for the development of active surfaces that promote cell adhesion. 
Polymeric films were developed in this work based on poly(maleic anhydride-alt-styrene) [PSMA] modified with amino acids of different hydropathic indices $(H)$ : L-glutamine $(H=-3.5), L$-tyrosine $(H=$ -1.3) and L-methionine ( $H=1.9),(17)$ with the aim of evaluating the effect of modifying film surface properties (wettability, surface energy, roughness and charge density) on the adhesion of human SHSY5Y neuroblastoma cells.

\section{EXPERIMENTAL SECTION}

\subsection{Materials}

The monomers maleic anhydride (MA) and styrene (S); the amino acids L-glutamine (GIn), Lmethionine (Met) and L-tyrosine (Tyr); and 3-aminopropyltriethoxysilane (APTES,> 98\%) were obtained commercially from Sigma-Aldrich. The $\mathrm{NaCl}$ and $\mathrm{NaHCO} 3$ salts and all the solvents used, including benzene, dimethylsulfoxide (DMSO), ethanol, 25\% ammonium hydroxide, hydrogen peroxide and deuterated dimethylsulfoxide (DMSO-D6) were obtained commercially from Merck. Silicon wafers were obtained commercially from Silicon Quest, USA. Deionized water $(0.055 \mu \mathrm{S} / \mathrm{cm})$ used to prepare the aqueous solutions was obtained from a LabStar 4-DI deionizer.

\subsection{Poly(maleic anhydride-alt-styrene) synthesis}

Poly(maleic anhydride-alt-styrene) copolymer, PSMA, with a molecular weight of $\mathrm{Mv}=6.3 \times 104 \mathrm{~g} / \mathrm{mol}$, was synthesized by radical polymerization by mixing equimolar amounts of previously purified styrene and maleic anhydride monomers, using anhydrous benzene as a solvent, and $8 \%$ of $\alpha, \alpha-$ azobisisobutyronitrile, AIBN, as the initiator. The synthesis was carried out at $60{ }^{\circ} \mathrm{C}$ in an N2 atmosphere for $2 \mathrm{~h}$.

\subsection{Determining PSMA Molecular Weight of PSMA}

The average viscosimetric molecular weight $(\mathrm{Mv})$ of the PSMA polymer of $63.000 \mathrm{~g} / \mathrm{mol}$ was determined by measuring the viscosity of PSMA solutions with THF as a solvent at $30^{\circ} \mathrm{C}$. The weight was calculated with the Mark-Houwink-Sakurada equation, using the constants $a=0.81$ and $k=5.07 \times 10$ 5. $(18,19)$

\subsection{Functionalizing PSMA with amino acids}

The PSMA copolymer was functionalized by mixing equimolar amounts of PSMA with the amino acids L-glutamine (GIn), L-methionine (Met) and L-tyrosine (Tyr), using DMSO as the solvent and $0.3 \%$ triethylamine (TEA) as a base at a constant temperature of $80^{\circ} \mathrm{C}$, under an $\mathrm{N} 2$ atmosphere (Scheme 1). The progress of the modification reactions was monitored by FT-IR spectroscopy. The final stage of the reaction was established when the bands at $1854 \mathrm{~cm}-1$ and $1779 \mathrm{~cm}-1$, which belong to the two carbonyl groups of maleic anhydride, disappeared and bands that belong to the carbonyls of the amide and carboxylic acid groups were observed at $\sim 1660 \mathrm{~cm}-1$ and $\sim 1710 \mathrm{~cm}-1$, respectively. (20) The disodium salts of the modified polymers were obtained by treating them with aqueous solutions of $\mathrm{NaHCO} 3$ (in a 1:2 polymer:NaHCO3 ratio) for 10 days. The solutions were then ultrafiltered and lyophilized. The salts of the polyelectrolytes obtained with the amino acids, Lglutamine, L-methionine and L-tyrosine, were respectively labeled PSMA-GIn, PSMA-Met and PSMA-Tyr. Their structures are represented in Scheme 2. 


\subsection{FT-IR Spectroscopy}

$\mathrm{KBr}$ discs were prepared with $2 \mathrm{mg}$ of polymer and $100 \mathrm{mg}$ of $\mathrm{KBr}$ to characterize pure PSMA and copolymers functionalized with amino acids. The FT-IR spectra were obtained with a Bruker Vector Model 22 at $25^{\circ} \mathrm{C}$.

\subsection{Magnetic resonance of proton and carbon-13 (1H-NMR and 13C-NMR)}

To study $1 \mathrm{H}-\mathrm{NMR}$ and 13C-NMR, $80 \mathrm{mg}$ of PSMA and of each copolymer functionalized with amino acids were dissolved in DMSO-D6 $(0.5 \mathrm{~mL})$. The $1 \mathrm{H}-\mathrm{NMR}$ and 13C-NMR spectra were examined using an Advance- 400 spectrometer at $25^{\circ} \mathrm{C}$.

\subsection{Quantitative elemental analysis}

Quantitative elemental compositions were determined in an elemental analyzer (CE Instruments, Eager 200 model). The samples were prepared in quantities of $2 \mathrm{mg}$ in tin crucibles, under a constant flow of helium and injection of oxygen gas.

\subsection{Polyelectrolyte adsorption on solid surfaces}

Polymeric solutions were prepared by dissolving the polyelectrolytes PSMA-GIn, PSMA-Met and PSMATyr in $0.001 \mathrm{M}$ and $0.1 \mathrm{M}$ solutions of $\mathrm{NaCl}$. The $\mathrm{pH}$ was adjusted to $\mathrm{pH} 4.0$ and $\mathrm{pH} 7.0$ by adding $\mathrm{HCl}$ or $\mathrm{NaOH}$ as appropriate. The concentration of the polyelectrolyte solutions varied between $1.0 \times 10-5$ $\mathrm{g} / \mathrm{L}$ and $1.0 \mathrm{~g} / \mathrm{L}$.

The silicon wafers used as substrates were chemically modified with 3-aminopropyltrimethoxysilane (APS) by oxidative washing (21) in order to obtain a homogeneousamino acid-terminated monolayer covalently bound to the silicon wafer. (22) Subsequently, the modified silicon wafers were immersed in $2 \mathrm{~mL}$ of the polyelectrolyte solutions for $3 \mathrm{~h}$, and then washed with deionized water and dried with an N2 flow. The quantity of polyelectrolytes adsorbed on the surface was determined by ellipsometry.

\subsection{Adsorption isotherms}

The adsorption isotherms were obtained by ex-situ ellipsometry in a variable angle ellipsometer L116S300 STOKES (Gaertner Scientific Corporation, USA) equipped with a HeNe laser with a wavelength of $\lambda=632.8 \mathrm{~nm}$ and an angle of incidence, $\Phi$ of $70^{\circ}$ at a temperature of $25 \pm 1{ }^{\circ} \mathrm{C}$. The quantity of polyelectrolyte adsorbed $\Gamma$ was determined according to the relationship between the thickness of the adsorbed layers, the concentration and the variation of the refractive index of the polyelectrolyte solutions. (23) The thickness of the adsorbed polyelectrolyte layer was calculated from the ellipsometric angles $\Delta$ and $\psi$ using a multilayer model composed of substrate-medium or substrate-unknown layer (APS or polyelectrolyte film), using the Elli computer program, based on the ellipsometry equation and iterative calculations with Jones matrices (24). The refractive indices $\mathrm{n}=$ 3.88 - i0.018 for pure silicon, $n=1.00$ for air and $n=1.462$ for thin layers of SiO2 were used to determine the thickness of the $\mathrm{SiO} 2$ layer. The average thickness obtained after several measurements was $1.2 \pm 0.2 \mathrm{~nm}$. To determine the APS monolayer, it is necessary to know the refractive indices $\mathrm{n}=$ 1.424 for APS and $n=1.00$ for air. (25). The thickness obtained for this layer after several measurements in air was $0.9-1.2 \mathrm{~nm}$.

\subsection{Polymeric Surface Wettability}

The wettability of the polymer surfaces was determined by contact angle measurements on the PSMAGIn, PSMA-Met and PSMA-Tyr films using a Drop Shape Analyzer DSA25S (KRUSS, Germany) controlled 
by Advance ${ }^{\circledR}$ software (KRUSS, Germany) using the Sessile Drop method at a temperature of $25{ }^{\circ} \mathrm{C}$. Water drops of $8 \mu \mathrm{L}$ were deposited to determine the advancing angle (qA) and drops of $4 \mu \mathrm{L}$ were deposited to determine the receding angle $(q R)$. Hysteresis $(D q=q A-q R)$ was determined as the difference between the advancing and the receding contact angles.

\subsection{Polymeric Surface Energy}

Droplets of $5 \mu \mathrm{L}$ of water or diiodomethane were deposited on PSMA-GIn, PSMA-Met and PSMA-Tyr films to determine surface energy. At least three measurements were made for each type of polymer surface with each type of solvent. The surface energy was calculated automatically by Advance ${ }^{\circledR}$ software (KRUSS, Germany) from the water and diiodomethane contact angles ( $\theta$ ) obtained once thermodynamic equilibrium was reached (as described by the Young-Laplace equation and the harmonic mean equation proposed by $\mathrm{Wu}$ ). The latter equation was developed from the surface tension ( $\gamma$ total) of a material, considered as the sum of its dispersive $(\gamma D)$ and polar components $(\gamma P)$ that best describe the interactions between a liquid and a polymeric surface with respect to other methods. (26-28)

\subsection{Polyelectrolytes film topography and surface potential}

The surfaces of the polyelectrolyte films were analyzed by atomic force microscopy (AFM) and Kelvin force microscopy (KFM) with an AFM/SPM Controller 9500 Series System, (Keysight Technologies, CA, USA) with a 7500 scanner. The surfaces were scanned in the magnetic-AC mode (MAC-Mode ${ }^{\circledR}$ Keysight) with a scan rate of $0.3 \mathrm{~Hz}$, using commercial AC200TS three-sided silicon probes (Olympus). The height and amplitude of AFM images were determined at room temperature (23-25 드). Commercial KS-HQ:XSC11/Pt umasch probes were used for the KFM. All Image analysis and root mean square (RMS) roughness was determined with Keysight PicoView software.

\subsection{Cells Culture and Cell Viability}

Human SH-SY5Y neuroblastoma cells (CRL-2266, American Type Culture Collection, Rockville, MD) were cultured (humid, 5\% CO2 atmosphere and 37으) in MEM-F12 medium supplemented with $10 \%$ FBS, non-essential amino acids, antibiotic-antimycotic mixture, and $20 \mathrm{mM}$ HEPES buffer, at pH 7.2. The cell culture medium was replaced every two days. The effect of the polyelectrolytes on cell viability was quantified by MTT assay following the manufacturer's instructions. Briefly, 5,000 cells were plated in each well of a 96-well microplate and cultured for 24 hours in the presence of different concentrations of polyelectrolyte solutions (in triplicate). The cell culture medium was replaced with $110 \mu \mathrm{L}$ of fresh medium supplemented with 1,1 mM MTT (3-(4,5-dimethylthiazol-2-yl)-2,5diphenyltetrazolium bromide) and incubated for 4 hours. Mitochondrial dependent formation of a colored product was terminated by adding $100 \mu \mathrm{L}$ of SDS-HCl solution, followed by 12 hours of solubilization at 37 ․ C. Absorbance as a measure of product formation was read at $570 \mathrm{~nm}$. (29)

\subsection{4-HNE immunofluorescence}

Cells grown on clean acid-washed cover slips (30) or fixed substrates (PSMA-GIn, PSMAMET or PSMATyr) were fixed with $4 \%$ paraformaldehyde, $4 \%$ sucrose in saline, permeabilized with $0.2 \%$ Triton-X100 in PBS, incubated overnight at $4^{\circ} \mathrm{C}$ with anti-HNE antibody (1:200), and then incubated with Alexa488-conjugated goat anti-rabbit IgG. The labeled cells were observed in a Zeiss LSM 710 confocal laser scanning microscope. Statistical significance was determined using a one-way ANOVA and Tukey posttest. 


\subsection{Scanning Electron Microscopy}

Cells grown on substrates (PSMA-GIn, PSMA-Met or PSMA-Tyr) were fixed with 4\% paraformaldehyde, $4 \%$ sucrose in saline, permeabilized with $0.2 \%$ Triton-X-100 in PBS, incubated overnight at $4^{\circ} \mathrm{C}$. Then the samples were then rinsed twice with PBS buffer at $\mathrm{pH} 7.0$ for $15 \mathrm{~min}$ and fixed with $1 \%$ glutaraldehyde in PBS buffer for $2 \mathrm{~h}$ at room temperature. The samples were then rinsed twice in PBS buffer. Finally, the samples were dehydrated in ascending grades of ethanol $(30,50,70,80,90$, and $100 \%$ ) and coated with a thin film of Pt/Pd.

\section{RESULTS AND DISCUSSION}

\subsection{Characterization of polyelectrolytes}

The FT-IR and 13C-NMR polyelectrolyte spectra were contrasted to the PSMA spectrum to provide a complementary confirmation of the successful modification of PSMA with the different amino acids by opening the maleic anhydride ring and forming an amide bond. The IR spectra (Figures 1-3 Supplementary Material) show that the characteristic bands of the $\mathrm{C}=\mathrm{O}$ maleic anhydride PSMA group at $1854 \mathrm{~cm}-1$ and $1779 \mathrm{~cm}-1$ disappear, while two new bands appear at $1664 \mathrm{~cm}-1$ and $1705 \mathrm{~cm}-1$ for PSMA-GIn, $1660 \mathrm{~cm}-1$ and $1703 \mathrm{~cm}-1$ for PSMA-Met, and $1637 \mathrm{~cm}-1$ and $1718 \mathrm{~cm}-1$ for PSMA-Tyr. These represent the stretching of the associated carbonyl group to an amide, and the stretching of the $\mathrm{C}=\mathrm{O}$ carboxylic acid group. The 13C-NMR PSMA spectra (Figures 4-5 Supplementary Material) show the characteristic signals of the $C$ atoms of the $C=0$ group of the PSMA anhydride at 172.9 and 173.58 ppm. After modification, these signals disappear and signals appear at 174.0 and $178.5 \mathrm{ppm}$ representing the $\mathrm{C}$ atoms of the $\mathrm{C}=\mathrm{O}$ groups of the carboxylic acids and the $\mathrm{C}=\mathrm{O}$ of the newly formed amide group. The percentages of modification for PSMA-GIn, PSMA-Met and PSMA-Tyr obtained by elemental analysis were respectively $81 \%, 98 \%$ and $80 \%$.

\subsection{Adsorption of polyelectrolytes on amino acid-terminated surfaces}

Polyelectrolyte adsorption is strongly influenced by $\mathrm{pH}$ level and salt concentration. Adsorption isotherms were obtained at $\mathrm{pH} 4.0$ and 7.0 , and at two salt concentrations, 0.1 and $0.001 \mathrm{M}$, to determine the type of interaction that governs adsorption behavior. The polyelectrolyte absorption rates at $\mathrm{pH} 4.0$ were higher for PSMA-GIn and PSMA-Tyr when the salt concentration was $0.1 \mathrm{M}$. This behavior is adjusted to what is termed "increased adsorption by shielding", which implies that the forces that modulate the interaction between the surface and polyelectrolyte are mainly of the hydrophobic type and can be explained by the screening of the charged segments of the polyelectrolyte with sodium counter ions. In this case, PSMA-GIn and PSMA-Tyr behave like a neutral polymer, while with PSMA-Met the electrolyte absorption rate decreases with the salt concentration at $0.1 \mathrm{M}$. This behavior is determined by the "decreased adsorption by shielding" described by Van der Steeg (31) and implies a modulating force. The interactions between the positively charged amino acidterminated surface and the $-\mathrm{COOH}$ group of the polyelectrolyte are mainly electrostatic.

The polyelectrolyte absorption rates at $\mathrm{pH} 7.0$ are lower than at $\mathrm{pH} 4.0$, but similar at the two salt concentrations (Table 1, Figure 1b) except for PSMA-Tyr. The pK1 of the PSMA-Tyr carboxylate group is 4.3 lower than the pK1 of PSMA-GIn and PSMA-Met (see Table 1). The lower pK1 value of PSMA-Tyr is associated with a larger number of carboxylic groups than with carboxylate groups. Considering that the propyl-amino group on the surface has a pKa close to $3.7,(32)$ it is expected that at pH 7.0 the absence of the amino acid-terminated surface charge promotes $\mathrm{H}$-bonding, and hydrophobic 
interactions between the phenol of the P-Tyr side chain and the amino acid-terminated surface, increasing the quantity of P-Tyr.

\subsection{Polyelectrolyte films wettability}

The advance contact angles $(\theta A)$ of the polyelectrolyte surfaces using deionized water as a solvent (Table 2) showed moderate effects of ionic strength and $\mathrm{pH}$ on the wettability of the polyelectrolytes films. At pH 4.0 and lower ionic strength, there were a larger number of charge groups because screening was reduced. Under this condition, the polyelectrolyte was more extended because charges are repulsed. In this case, PSMA-GIn and PSMA-Tyr adopted looplike shapes that expose the phenyl group of the main polymer chain to the air, resulting in hydrophobic domains in the polyelectrolyte film, while PSMA-Met exposed the -COO- group of main chain, resulting in a surface with a less hydrophobic character. As was expected, the deprotonated carboxyl groups of the side chain of PSMAMet interacted with the amino groups of the amino acid-terminated surface through electrostatic interactions. PSMA-GIn H-bonding between the amino groups of the side chain and the amino acidterminated surfaces favored exposing hydrophobic residues to the air at $\mathrm{pH} 4.0$ and high ionic strength, so that there was more screening of -COO- groups of lateral and main chain of polyelectrolytes and therefore the polyelectrolytes behaved as neutral polymers when the chains are coiled due to the intra or inter molecular interactions. Under these conditions, the PSMA-Tyr film is hydrophobic, likely because aromatic styrene rings and the side chain are exposed to the air, thus decreasing the wettability of the film and giving it a more hydrophobic character.

A slight effect of the hydropathic amino acid index on polyelectrolyte wettability is observed at pH 7.0 and the higher ionic strength, while at the lower ionic strength, the PSMA-GIn film is more hydrophobic, even when the Gln hydropathic index is negative (hydrophilic). This $\mathrm{pH}$ value corroborates that the amino groups of the PSMA-GIn side chain interact by $\mathrm{H}$-bonding with the amino groups of the modified surface, leaving a greater number of phenyls of main chain groups exposed to the surface.

In most cases, the polyelectrolytes adsorbed onto the amino acid-terminated surface, exposing a mixture of hydrophilic and hydrophobic groups in their structures, which is reflected in the high hysteresis values, and therefore the surfaces are rather heterogeneous chemically, given the presence of polar groups and hydrophobic residues in the polyelectrolyte structures. Considering that the highest amount of adsorbed polyelectrolyte occurred at pH 4.0, studies of surface energy, topography, surface potential and cell adhesion were performed on films prepared at $\mathrm{pH} 4.0$ at low and high ionic strength.

\subsection{Surface Energy of Polymeric Films}

Table 3 shows the contact angles obtained using the polar-non-polar solvent pairs of water and diiodomethane, and the surface energy determined for the polyelectrolyte films. The surface energy values of all the polyelectrolyte films are relatively similar (in a range of 53 to $59 \mathrm{~mJ} / \mathrm{m} 2$ ) regardless of the amount of salt added, while the surface energy values of the unmodified polyelectrolyte were higher ( 62 to $63.16 \mathrm{~mJ} / \mathrm{m} 2$ ). The surface energy of organic polymeric materials can be classified as low, medium and high. Low surface energy levels were in the range of 10 to $30 \mathrm{~mJ} / \mathrm{m} 2$. Medium surface energy is between $30-40 \mathrm{~mJ} / \mathrm{m} 2$ and solid surface high energy surfaces are above $40 \mathrm{~mJ} / \mathrm{m} 2$. (33) Therefore, the polymer films obtained in this work can be considered as having high surface energy. The relative contributions of the components to surface energy $(\gamma)$ are determined by the chemical composition of the surface. The polar component $(\gamma \mathrm{P})$ is composed of several polar interactions that 
include hydrogen bridges, dipoledipole interaction and induction energy, while the dispersive component $(\gamma D)$ is mainly due to London dispersion forces.

Figure 2 shows that the dispersive component of the surface energy of all the polymeric films is much greater than the polar component, which suggests that the governing interactions are London dispersion forces and to a lesser extent dipole-dipole interactions or hydrogen bridges. This confirms the theory that polyelectrolytes are adsorbed on the hydrophilic surface in a ydrophobic/hydrophilic balance between their side chains and the hydrophobic groups of the main chain, as suggested by the wettability of the films.

\subsection{Polymeric Film Topography, Roughness and Surface Potential}

Following the incubation, the grafted APS silicon surfaces were removed from the polyelectrolyte solution prepared at one of two levels of ionic strength; 0.001 and $0.1 \mathrm{M} \mathrm{NaCl}$, rinsed, and dried with $\mathrm{N} 2$ stream, and then immediately analyzed by the atomic force microscopy (AFM). The AFM images in Figure 3 show the surface morphology of the polyelectrolyte films on the APS grafted silicon surfaces after incubation. Very homogeneous and regular polymer deposits are observed in all cases and at both ionic strengths. Two kinds of morphology were adopted, a well-defined globular nanostructure for PSMA-Met and PSMA-Tyr, and a densely packed nanofibrous-like structure for PSMA-GIn. Ionic strength affected the nanostructures forming polyelectrolyte surfaces. Although the surface morphology domains were preserved in both cases, the higher ionic strength value caused a slight decrease in size of the nanostructures forming the surface domains, which was reflected in surface roughness values. Table 4 shows that for all the electrolytes, surface roughness was greater with the lower ionic strength. At $1 \mathrm{mM} \mathrm{NaCl}$, the shielding effect of the $\mathrm{Na}+$ counter ion on the charged polyelectrolyte is low and consequently there is a large number of charged groups in polymer network where electrostatic repulsion takes place. This results in the polymer being more extended on the APS grafted silicon surface, with consequent increased surface roughness. These surface morphology and roughness parameters are consistent with what is described above regarding polyelectrolyte film wettability and surface energy.

Surface potential results using Kelvin force microscopy (frequency modulation) (KFM) for PSMA, PSMAGIn, PSMA-Met and PSMA-Tyr were respectively 81, 39, 23 and $14 \mathrm{mV}$. These results show higher surface potential values for PSMA and PSMA-GIn. The pKa1 and pKa2 values were respectively 2.9 and 6.4 for PSMA, and 4.3 and 8.2 PSMA-GIn. These values indicate that at $\mathrm{pH} 4.0$ there are groups, $-\mathrm{COOH}$ and-COO-, with the latter contributing to electrostatic repulsion in the main and lateral chains of the polyelectrolyte. This behavior concurs with the type of 2D nanostructure observed in the PSMA and PSMA-GIn films, which concurs with the low RMS value obtained. It has been reported that an increase in the charge density of a polyelectrolyte induces the adsorption of chains parallel to the surface because a more extended shape is adopted that results in flatter films and a higher surface charge. (34) PSMA-Met and PSMA-Tyr behaved differently in that the hydrophilic/hydrophobic balance of the carboxylic groups (protonated and deprotonated), phenyl groups and - $\mathrm{CH} 2$ - groups in side chain, generated less repulsion between the charged segments. In this case, hydrophobic interactions and the hydrogen bridge are more important, giving rise to globular nanostructures (3D) that contributed to increased surface roughness. Studies indicate that the correlation between the potential difference and the roughness of polyelectrolyte films derived from poly(maleic anhydride-altstyrene) depends mainly on the hydrophobic character of the polyelectrolyte side chain. (35) 


\subsection{Cell response to PSMA modified substrates}

25,000 SH-SY5Y neuroblastoma cells were plated on UV-light sterilized PSMA coated silicon surfaces $(1 \mathrm{~cm} 2)$, with aforementioned amino acid functionalization. They were compared to cells growing on glass coverslips (in the presence or absence of polylysine). Random fields were photographed under phase contrast microscopy and cells per field was counted in a double-blind fashion at 24, 48 and 72 hours. As can be seen in Figure 4, the cell number per field was consistently and proportionally higher at hour 27 hour/doubling time reported for these cells, (36) suggesting that SH-SY5Y cell proliferation was not significantly affected by the different PSMA modified substrates.

The functionalized PSMA substrates elicited different responses from SH-SY5Y neuroblastoma cells, likely reflecting the differences in hydrophilicity/hydrophobicity of the exposed surface. As can be observed in Figure 5, SH-SY5Y cells spread easily over acid-washed glass coverslips in the absence or presence of a polylysine coating. In contrast, amino-acid functionalized PSMA-polyelectrolytes significantly diminished the spread of cells compared to standard substrates. Only PSMA-Met appeared to induce an increase in lipid peroxidation, which could be interpreted as a stress signal or a change in cell metabolism (Figures $5 \mathrm{~B}$ and $\mathrm{C}$ respectively). The treatments did not affect cell viability, as measured by the MTT assay (Figure 5D), which suggests that PSMA-Met modifies SH-SY5Y neuroblastoma response to the substrate.

As can be seen in Figure 6, differences in the shape of SH-SY5Y cells reflects their sensitivity distinct PMSA-substrate characteristics. Control cells (glass and polylysine, respectively) consistently present fusiform (two processes) or pyramidal shapes (three processes) characteristic of undifferentiated SHSY5Y. These cells also present well defined actin-rich areas that are consistent with focal adhesion. When cultured on PSMA-Met, SH-SY5Y cells present a stellate shape, with 5 or more actin-rich thin processes that extend $5 \mu \mathrm{m}$ or more from the cell body. In contrast, when seeded on PSMA-GIn, SHSY5Y cells have a round morphology, with fewer and shorter processes. The shape suggests that these cells are in a higher state of proliferation, an effect that did not appear to be significant when cell proliferation was assessed (Figure 4). While suggestive, these results do not shed light on whether PSMA-GIn substrates inhibit neuroblastoma cell proliferation or PSMA-Met substrates induce cell differentiation.

Figure 7 shows the morphology of the SH-SY5Y cells cultured on the surface of PMSA, PMSA-GIn, PMSAMet and PMSA-Tyr. The cells cultured on PSMA-Met have a well-extended morphology, characterized by a much larger cell area than that of cells cultured on PSMA-GIn and PSMA-Tyr, as can be seen in Figure 6. Cells on the surface of unmodified PSMA and PSMA-Tyr have a spindle-like morphology characterized by a small cell area and a high aspect ratio. The well-extended morphology that predominates on the surface of PSMA-Met is associated with its moderate hydrophilicity and topography. Although the hydropathic index of PSMA-Met is the most positive (hydrophobic), the orientation and conformation of PSMA-Met allows for obtaining a surface of moderate hydrophilicity associated with the heterogeneity of the hydrophilic domains due to its polar (- $\mathrm{COOH}$ and $-\mathrm{NH} 2$ ) groups in its main and lateral chains. Some works have related the optimal adhesion of neuronal cells with a greater formation of neurites on surfaces of moderate hydrophilicity. (37) The wettability of the surfaces has been related to the ability of the surface to adsorb proteins from the serum, $(38,39)$ what would facilitate the cell adhesion. Another factor to consider could be related to the roughness of the surface, it has been reported that rougher surfaces achieve a positive response in the cellular adhesion 
of SH-SY5Y, while other authors have shown that roughness can play minor functions in the response mobile. $(40,41)$ In our case, the roughness of the surface is determined by the effects of repulsion or formation of aggregates given by the presence of charged groups (-COO-group) as well as the chemical functionality of polyelectrolytes. The contribution of these effects is reflected in the surface potential values, where the highest values are associated with repulsive effects (PSMA and PSMA-GIn) while the lowest values are related to hydrophobic or hydrogen bridge interactions. For this last case, the associative interactions would promote the adhesion of SH-SY5Y.

\section{CONCLUSIONS}

The adsorption behavior of polyelectrolytes functionalized with amino acids on an amino acidterminated surface depends on the chemical nature of the polyelectrolyte side chain, its ionic strength and the $\mathrm{pH}$ level of the solution. The largest quantity of polyelectrolytes adsorbed was at $\mathrm{pH}$ 4.0 and high ionic strength, with more polyelectrolytes adsorbed by the glutamine and tyrosine films than by the methionine film. The contact angle measurements of the polyelectrolyte films showed that wettability at $\mathrm{pH} 4.0$ is governed by the hydrophilic/hydrophobic balance given by hydrophobic domains of the main polyelectrolyte chain, and by the nature of amino acid moiety, while that at $\mathrm{pH}$ 7.0 there was an evident contribution of the effect of the hydropathic amino acid index on polyelectrolyte wettability. The AFM images of polyelectrolyte surfaces showed two kinds of morphology, a well-defined globular nanostructure for PSMA-Met and PSMA-Tyr, and a densely packed nanofibrous-like structure for PSMA-GIn. Cell adhesion assays showed that SH-SY5Y cells cultured on PSMAMet had a well-extended morphology, characterized by much larger stellate shaped cells, with five or more actin-rich thin processes, while SH-SY5Y cells that were seeded on PSMA-GIn and PSMA-Tyr have a round morphology, with fewer and shorter processes.

These results indicate that it is possible to modulate the surface characteristics of polyelectrolyte films based on their chemical functionality and environmental parameters such as $\mathrm{pH}$ and ionic strength, in order to evaluate their effect on cell adhesion.

In conclusion, films obtained from polyelectrolytes functionalized with amino acids can be a simple and low-cost platform for cell adhesion control aimed at developing biomaterials with modified surface properties.

Supporting Information: FT-IR spectra of: PSMA and PSMA-GIn, PSMA-Met and PSMA-Tyr. 13C-NMR spectra of: PSMA, PSMA-GIn, PSMA-Met and PSMA-Tyr (PDF).

\section{Author Contributions}

The manuscript was written through contributions of all authors. All authors have given approval to the final version of the manuscript. These authors contributed equally. M.S. Leal, $+\mathrm{X}$. Briones, $+\mathrm{V}$. Villalobos, † Y. Queneau, ‡ A. Leiva,§ H.E. Ríos, † A. Roth, | J. Pavez, || C. Silva, || C. Carrasco, | Andrónico Neira-Carrillo, $\infty$ L. Tamayo, ${ }^{*+}$ M.D. Urzúa, ${ }^{* \dagger}$ 
Funding Sources

FONDECYT 1151221 and 1100240, FONDECYT Iniciación grant 11160230, ANILLO ACT- 1412, PAICONICYT 79170015, FONDEQUIP EQM160036.

\section{ACKNOWLEDGMENT}

The authors are grateful to FONDECYT 1151221, FONDECYT 1100240, ANILLO ACT-1412 Project and FONDECYT Iniciación grant 11160230, PAI-CONICYT 79170015, and FONDEQUIP EQM160036.

\section{REFERENCES}

(1) Waugh, D. G.; Toccaceli, C.; Gillett, A. R.; Ng, C. H.; Hodgson, S. D.; Lawrence, J. Surface Treatments to Modulate Bioadhesion: A Critical Review. Rev. Adhes. Adhes. 2016, 4, 69-103. DOI: DOI: 10.7569/RAA.2016.097304

(2) Guo, S.; Zhu. X,; Li, M.; Shi, L., Ong, J.L.T.; Jańczewski, D.; Neoh, K.G. Parallel Control over Surface Charge and Wettability Using Polyelectrolyte Architecture: Effect on Protein Adsorption and Cell Adhesion. ACS Appl. Mater. Interfaces. 2016, 8, 30552-30563. DOI: 10.1021/acsami.6b09481

(3) Khan, S.; Newaz, G. A Comprehensive Review of Surface Modification For Neural Cell Adhesion and Patterning. J. Biomed. Mater. Res. A. 2010, 93, 1209-1224. DOI: 10.1002/jbm.a.32698

(4) Lee, I. Molecular Self-Assembly: Smart Design of Surface and Interface Via Secondary Molecular Interactions. Langmuir. 2013, 29, 2476-2489. DOI: 10.1021/la304123b

(5) Hardy, A.; Seguin, C.; Brion, A.; Lavalle, P.; Schaaf, P.; Fournel, S.; Bourel-Bonnet, L.; Frisch, B.; De Giorgi, M. $\beta$-Cyclodextrin-Functionalized Chitosan/Alginate Compact Polyelectrolyte Complexes (COPECS) as Functional Biomaterials with Anti-Inflammatory Properties. ACS Appl. Mater. Interfaces. 2018, 10, 29347-29356. DOI: 10.1021/acsami.8b09733

(6) Sanandiya, N. D.; Lee, S.; Rho, S.; Lee, H.; Kim, I. S.; Hwang, D. S. Tunichrome-inspired Pyrogallol Functionalized Chitosan for Tissue Adhesion and Hemostasis. Carbohydr. Polym. 2019, 208, 77-85. DOI: 10.1016/j.carbpol.2018.12.017

(7) Hwang, M. P.; Ding, X.; Gao, J.; Acharya, A. P.; Little, S. R.; Wang, Y. A biocompatible betainefunctionalized polycation for coacervation. Soft Matter. 2018, 14, 387-395. DOI: 10.1039/C7SM01763D (8) Gao, Y.; Xu, Z.; Chen, S.; Gu, W.; Chen, L.; Li, Y. Arginine-Chitosan/DNA Self-Assemble Nanoparticles for Gene Delivery: In Vitro Characteristics and Transfection Efficiency. Int. J. Pharm. 2018, 359, 241246. DOI: 10.1016/j.ijpharm.2008.03.037

(9) Lv, H. X.; Zhang, Z. H.; Wang, X. P.; Cheng, Q. Q.; Wang, W.; Huang, X. H.; Zou, J. P.; Zhang, Q, Hou, L. L.; Huo, W. A Biomimetic Chitosan Derivates: Preparation, Characterization and Transdermal Enhancement Studies Of N-Arginine Chitosan. Molecules. 2011, 16, 6778- 6790. DOI: 10.3390/molecules 16086778

(10) Park, H.; Choi, B.; Nguyen, J.; Fan, J.; Shafi, S.; Klokkevold, P.; Lee, M. Anionic CarbohydrateContaining Chitosan Scaffolds for Bone Regeneration. Carbohydr. Polym. 2013, 97, 587-596. DOI: 10.1016/j.carbpol.2013.05.023

(11) Ho, M. H.; Wang, D. M.; Hsieh, H. J.; Liu, H. C.; Hsien, T. Y.; Lai, J. Y.; Hou, L. T. Preparation and Characterization of RGD-immobilized Chitosan Scaffolds. Biomaterials. 2005, 26, 3197-3206. DOI: 10.1016/j.biomaterials.2004.08.032

(12) Kim, S.; Cui, Z. K.; Fan, J.; Fartash, A.; Aghaloo, T. L.; Lee, M. Photocrosslinkable Chitosan Hydrogels Functionalized with the RGD Peptide and Phosphoserine to Enhance Osteogenesis. J. Mater. Chem. B. 2016, 4, 5289-5298. DOI: 10.1039/C6TB01154C 
(13) Tu, H. P.; Lee, X. Q.; Lin, C. Y.; Shen, E. C.; Chen, Y. T.; Fu, E.; Chin, Y. T. Enhanced Attachment and Growth of Periodontal Cells on Glycine-Arginine-Glycine-Aspartic Modified Chitosan Membranes. J. Med. Sci. 2016, 36, 137. DOI: 10.4103/1011-4564.188898

(14) LogithKumar, R.; KeshavNarayan, A.; Dhivya, S.; Chawla, A.; Saravanan, S.; Selvamurugan, N. A Review of Chitosan and Its Derivatives in Bone Tissue Engineering. Carbohydr. Polym. 2016, 151, $172-$ 188. DOI: 10.1016/j.carbpol.2016.05.049

(15) Jones, D. S.; Laverty, T. P.; Morris, C.; Andrews, G. P. Statistical modelling of the rheological and mucoadhesive properties of aqueous poly (methylvinylether-co-maleic acid) networks: Redefining Biomedical Applications and the Relationship Between Viscoelasticity and Mucoadhesion. Colloids Surf. B. 2016, 144, 125-134. https://doi.org/10.1016/j.colsurfb.2016.03.008

(16) Pompe, T.; Zschoche, S.; Herold, N.; Salchert, K.; Gouzy, M. F.; Sperling, C.; Werner, C. Maleic Anhydride Copolymers a Versatile Platform for Molecular Biosurface Engineering. Biomacromolecules. 2003, 4, 1072-1079. https://doi.org/10.1021/bm034071c

(17) Kyte, J.; Doolittle, R. F. A Simple Method for Displaying the Hydropathic Character of a Protein. J. Mol. Biol. 1982, 157, 105-132. https://doi.org/10.1016/0022-2836(82)90515-0

(18) Briones, X.G.; Encinas, M.V.; Petri, D.F.S.; Pavez, J.E.; Tapia, R.A.; Yazdani-Pedram, M.; Urzúa, M.D. Adsorption Behavior of Hydrophobically Modified Polyelectrolytes onto Amino- or Methyl-Terminated Surfaces. Langmuir. 2011, 27, 13524-13532. https://doi.org/ 10.1021/la2025632

(19) Ohno, N.; Nitta, K.; Makino, S.; Sugai, S. Conformational transition of the copolymer of maleic acid and styrene in aqueous solution. J. Polym. Sci. B. 1973, 11, 413-425. https://doi.org/10.1002/pol.1973.180110302

(20) Pretsch, E.; Buehlmann, P.; Affolter, C.; Pretsch, E.; Bhuhlmann, P.; Affolter, C. 2000. Structure Determination of Organic Compounds (p. 108). Berlin: Springer-Verlag.

(21) Siqueira Petri, D. F.; Wenz, G., Schunk, P.; Schimmel, T. An Improved Method for the Assembly of Amino-Terminated Monolayers on SiO2 and the Vapor Deposition of Gold Layers. Langmuir. 1999, 15, 4520-4523. https://doi.org/ 10.1021/la981379u

(22) Motschmann, H.; Stamm, M.; Toprakcioglu, C. Adsorption Kinetics of Block Copolymers from a Good Solvent: A Two-Stage Process. Macromolecules. 1991, 24, 3681-3688. https://doi.org/10.1021/ma00012a032

(23) De Feijter, J.; Benjamins, D. J.; Veer, F. A. Ellipsometry as a tool to study the adsorption behavior of synthetic and biopolymers at the air-water interface. Biopolymers. 1978, 17, 1759-1772. https://doi.org/10.1002/bip.1978.360170711

(24) Azzam, R. M. A.; Bashara, N. M. Ellipsometry and Polarized Light, North-Holland Publ. Co., Amsterdam 1977. https://doi.org/10.1063/1.2994821

(25) Urzúa, M.D.; Briones, X.G.; Carrasco, L.P.; Encinas M.V.; Petri, D.F.S. Adsorption of Anionic Amphiphilic Polyelectrolytes onto Amino-Terminated Solid Surfaces. Polymer. 2010, 51, 3445-3452. https://doi.org/10.1016/j.polymer.2010.05.054

(26) Wu, S. (1971). Calculation of interfacial tension in polymer systems. In Journal of Polymer Science Part C: Polymer Symposia (Vol. 34, No. 1, pp. 19-30). New York: Wiley Subscription Services, Inc., A Wiley Company. https://doi.org/10.1002/polc.5070340105

(27) Wu S. (1982) Polymer Interface and Adhesion: Taylor \& Francis; 630 pp. (28) Kosaka, P. M.; Kawano, Y.; Petri, D. F. S. Dewetting and Surface Properties of Ultrathin Films of Cellulose Esters. J. Colloid and Interface Sci. 2007, 316, 671-677. https://doi.org/10.1016/j.jcis.2007.07.058 
(29) Mosmann, T. Rapid colorimetric assay for cellular growth and survival: application to proliferation and cytotoxicity assays. J. Immunol. Methods. 1983, 65, 55-63. https://doi.org/10.1016/00221759(83)90303-4

(30) Preparation of Slides and Coverslips for Microscopy. Andrew H. Fischer, Kenneth A. Jacobson, Jack Rose and Rolf Zeller Cold Spring Harb Protoc 2008. https://doi.org/10.1101/pdb.prot4988

(31) Van de Steeg, H.G.M.; Cohen Stuart M.A.; De Keizer A.; Bijsterbosch, B.H. Polyelectrolyte Adsorption: A Subtle Balance of Forces. Langmuir. 1992, 8, 2538-2546. https://doi.org/10.1021/la00046a030

(32) Fujimoto, J.; Petri, D.F.S. Adsorption Behavior of Carboxymethylcellulose on Amino-Terminated Surfaces. Langmuir, 2001, 17,56-60. https://doi.org/10.1021/la000731c

(33) Wake, W. C. (1988). Adhesion and Adhesives: Science and Technology. AJ Kinloch, Chapman and Hall, London.

(34) Llamas, S.; Guzman, E.; Ortega, F.; Baghdadli, N.; Cazeneuve, C.; Rubio, R. G.; Luengo, G. S. Adsorption of Polyelectrolytes and Polyelectrolytes-Surfactant Mixtures at Surfaces: A PhysicoChemical Approach to a Cosmetic Challenge. Adv. Colloid Interface Sci. 2015, 222, 461-487. https://doi.org/10.1016/j.cis.2014.05.007

(35) Briones, X. G.; Urzúa, M. D.; Ríos, H. E.; Espinoza-Beltrán, F. J.; Dabirian, R.; Yazdani-Pedram, M. Thin Films of Amphiphilic Polyelectrolytes. Soft Materials Characterized by Kelvin Probe Force Microscopy. Polymer. 2013, 54, 5733-5740. https://doi.org/10.1016/j.polymer.2013.07.066

(36) Kovalevich, J.; Langford, D. (2013). Considerations for the use of SH-SY5Y neuroblastoma cells in neurobiology. In Neuronal Cell Culture (pp. 9-21). Humana Press, Totowa, NJ. https://doi.org/10.1007/978-1-62703-640-5_2

(37) Lee, S. J.; Khang, G.; Lee, Y. M.; Lee, H. B. The Effect of Surface Wettability on Induction and Growth of Neurites from the PC-12 Cell on a Polymer Surface. J. Colloid Interface Sci. 2003, 259, 228- 235. https://doi.org/10.1016/S0021-9797(02)00163-7

(38) Wei, J.; Igarashi, T.; Okumori, N.; Igarashi, T.; Maetani, T.; Liu, B.; Yoshinari, M. Influence of Surface Wettability on Competitive Protein Adsorption and Initial Attachment of Osteoblasts. Biomed. Mater. 2009, 4, 45002. https://doi.org/10.1088/1748-6041/4/4/045002

(39) Arima, Y.; Iwata, H. Effect of wettability and surface functional groups on protein adsorption and cell adhesion using well-defined mixed self-assembled monolayers. Biomaterials. 2007, 28, 30743082. https://doi.org/10.1016/j.biomaterials.2007.03.013

(40) Prévôt, M. E.; Bergquist, L. E.; Sharma, A.; Mori, T.; Gao, Y.; Bera, T.; Zhu, C.; Leslie, M. T.; Cukelj, R.; Korley, L. T. J.; Freeman, E. J.; McDonough J. A.; Clements, R. J.; Hegmann, E. (2017, August). New developments in 3D liquid crystal elastomers scaffolds for tissue engineering: from physical template to responsive substrate. In Liquid Crystals XXI (Vol. 10361, p. 103610T). International Society for Optics and Photonics. https://doi.org/10.1117/12.2275338

(41) Genchi, G. G., Ceseracciu, L., Marino, A., Labardi, M., Marras, S., Pignatelli, F., Bruschini, L.; Matolli, V.; Ciofani, G. (2016). P(VDF-TrFE)/BaTiO3 Nanoparticle Composite Films Mediate Piezoelectric Stimulation and Promote Differentiation of SH-SY5Y Neuroblastoma Cells. Adv. Healthc. Mater. 2016, 5, 1808-1820. https://doi.org/10.1002/adhm.201600245 
Table 1. Experimental pKapp values for polyelectrolytes and reported pKa values for amino acids

\begin{tabular}{cccccc} 
& \multicolumn{2}{c}{ Polyelectrolyte $\mathrm{pKapp}$} & \multicolumn{2}{c}{ Amino acids $\mathrm{pKa}$} & \\
\cline { 2 - 5 } Amino acid & $\begin{array}{c}\mathrm{pK}_{\text {app } 1} \\
\text {-COO'group }^{-}\end{array}$ & $\begin{array}{c}\mathrm{pK}_{\text {app } 2} \\
\text {-COO'group }\end{array}$ & $\begin{array}{c}\mathrm{pKa}_{1} \\
\text {-COO'group }^{-}\end{array}$ & $\begin{array}{c}\mathrm{pKa}_{2} \\
-\mathrm{NH}_{3}{ }^{+} \text {group }\end{array}$ & \\
\hline Gln & 4.90 & 8.20 & 2.17 & 9.13 & -3.5 \\
Met & 4.90 & 7.90 & 2.28 & 9.21 & 1.9 \\
Tyr & 4.30 & 8.20 & 2.20 & 9.11 & -1.3
\end{tabular}

Table 2. Advancing $(\theta A)$ and receding $(\theta R)$ contact angles and hysteresis $(\Delta \theta)$ in the contact angle for PSMA-GIn, PSMA-Met and PSMA-Tyr of $6.3 \times 104 \mathrm{~g} / \mathrm{mol}$ at the $0.5 \mathrm{~g} / \mathrm{L}$ adsorbed on hydrophilic surfaces at 0.1 and $0.001 \mathrm{~mol} / \mathrm{L} \mathrm{NaCl}$ and at $\mathrm{pH} 4.0$ and $\mathrm{pH} 7.0$

\begin{tabular}{|c|c|c|c|c|c|}
\hline $\mathrm{pH}$ & $\underset{(\mathrm{mol} / \mathrm{L})}{\mathrm{C}_{\mathrm{var}}}$ & $\begin{array}{l}\text { Polyelectrolyte } \\
\text { Film }\end{array}$ & $\theta_{A}\left({ }^{\circ}\right)$ & $\theta_{\mathrm{R}}\left({ }^{\circ}\right)$ & $\Delta \theta\left({ }^{\circ}\right)$ \\
\hline \multirow{8}{*}{4.0} & \multirow{4}{*}{0.001} & PSMA & $67 \pm 1$ & $59 \pm 1$ & $8 \pm 1$ \\
\hline & & PSMA-Gln & $68 \pm 1$ & $45 \pm 1$ & $23 \pm 1$ \\
\hline & & PSMA-Met & $60 \pm 3$ & $38 \pm 2$ & $22 \pm 3$ \\
\hline & & PSMA-Tyr & $66 \pm 1$ & $47 \pm 2$ & $19 \pm 2$ \\
\hline & \multirow{4}{*}{0.1} & PSMA & $67 \pm 2$ & $44 \pm 2$ & $23 \pm 2$ \\
\hline & & PSMA-Gln & $69 \pm 1$ & $54 \pm 2$ & $15 \pm 2$ \\
\hline & & PSMA-Met & $67 \pm 1$ & $59 \pm 1$ & $8 \pm 1$ \\
\hline & & PSMA-Tyr & $68 \pm 1$ & $45 \pm 1$ & $23 \pm 1$ \\
\hline \multirow{8}{*}{7.0} & \multirow{4}{*}{0.001} & PSMA & $53 \pm 2$ & $38 \pm 5$ & $15 \pm 4$ \\
\hline & & PSMA-Gln & $68 \pm 2$ & $41 \pm 2$ & $27 \pm 2$ \\
\hline & & PSMA-Met & $61 \pm 2$ & $40 \pm 2$ & $21 \pm 2$ \\
\hline & & PSMA-Tyr & $58 \pm 1$ & $35 \pm 2$ & $23 \pm 2$ \\
\hline & \multirow{4}{*}{0.1} & PSMA & $50 \pm 2$ & $31 \pm 3$ & $19 \pm 3$ \\
\hline & & PSMA-Gln & $72 \pm 1$ & $53 \pm 1$ & $19 \pm 1$ \\
\hline & & PSMA-Met & $74 \pm 3$ & $48 \pm 1$ & $26 \pm 2$ \\
\hline & & PSMA-Tyr & $73 \pm 1$ & $50 \pm 3$ & $23 \pm 2$ \\
\hline
\end{tabular}


Table 3. Contact angles of the water-diiodomethane pairs and surface energy (with polar and dispersive components) of the polymer films obtained at different ionic strengths at $\mathrm{pH}$ 4.0.

\begin{tabular}{|c|c|c|c|c|c|c|}
\hline $\begin{array}{c}\mathrm{C}_{\mathrm{NuCl}} \\
(\mathrm{mol} / \mathrm{L})\end{array}$ & $\begin{array}{l}\text { Polyelectrolyte } \\
\text { Film }\end{array}$ & $\begin{array}{l}\theta_{\text {water }} \\
\left({ }^{\circ}\right)\end{array}$ & $\begin{array}{c}\theta_{\text {diiodbenehene }} \\
\left({ }^{\circ}\right)\end{array}$ & $\begin{array}{c}\gamma^{\mathrm{D}} \\
\left(\mathrm{mJ} / \mathrm{m}^{2}\right)\end{array}$ & $\begin{array}{c}\gamma^{\mathrm{P}} \\
\left(\mathrm{mJ} / \mathrm{m}^{2}\right)\end{array}$ & $\begin{array}{c}\gamma \\
\left(\mathrm{m} / / \mathrm{m}^{2}\right)\end{array}$ \\
\hline \multirow{4}{*}{0.001} & PSMA & $67 \pm 1$ & $41 \pm 1$ & 39.53 & 23.63 & 63.16 \\
\hline & PSMA-Gln & $68 \pm 1$ & $44 \pm 1$ & 38.12 & 14.94 & 53.06 \\
\hline & PSMA-Met & $60 \pm 3$ & $33 \pm 1$ & 43.15 & 13.49 & 56.59 \\
\hline & PSMA-Tyr & $66 \pm 1$ & $39 \pm 1$ & 40.84 & 17.55 & 58.39 \\
\hline \multirow{4}{*}{0.1} & PSMA & $67 \pm 1$ & $42 \pm 1$ & 39.32 & 22.69 & 62.00 \\
\hline & PSMA-Gln & $69 \pm 1$ & $38 \pm 2$ & 40.89 & 14.90 & 55.79 \\
\hline & PSMA-Met & $67 \pm 2$ & $41 \pm 2$ & 39.53 & 14.41 & 53.95 \\
\hline & PSMA-Tyr & $68 \pm 1$ & $42 \pm 3$ & 39.45 & 13.74 & 53.20 \\
\hline
\end{tabular}

Table 4. RMS of the polymeric films obtained at different ionic strengths at $\mathrm{pH} 4.0$

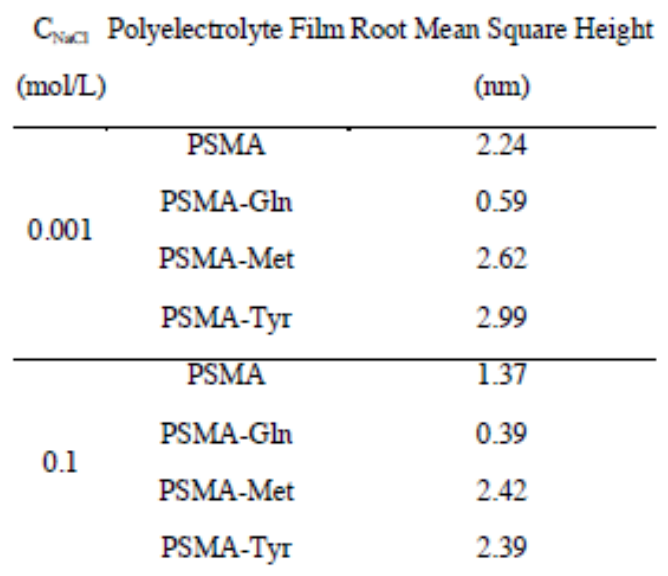


<smiles>O=C1C=CC(=O)O1</smiles>

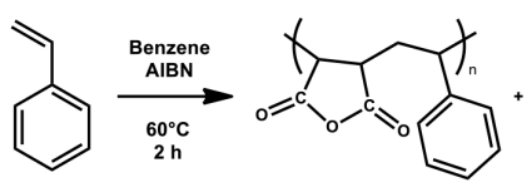<smiles>[2H]C(N)C(=O)O</smiles><smiles>CC(C#N)CC(C)C#N</smiles><smiles>CC(C)(C)C(CC(C(=O)N[C@@H](P)C(=O)O)C(C)(C)C)C(=O)O</smiles>

$R=$<smiles>CCCC(N)=O</smiles>

Gin b)

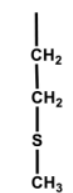

Met<smiles>CCc1ccc(O)cc1</smiles>

$\mathrm{NaHCO}_{3}$<smiles>COC(=O)[C@H](P)NC(=O)C(CC(c1ccccc1)C(C)(C)C)C(C(=O)O)C(=O)O[18O]</smiles>

Scheme 1. Reactions to obtain salts from polyelectrolytes derived from PSMA modified with amino acids. $R$ represents the side groups of the amino acids: a) glutamine, b) methionine and c) tyrosine.<smiles>COC(=O)[C@H](CCC(N)=O)NC(=O)C(CC(C(C)(C)C)C(C)(C)C)C(=O)O[Na]</smiles>

PSMA-GIn

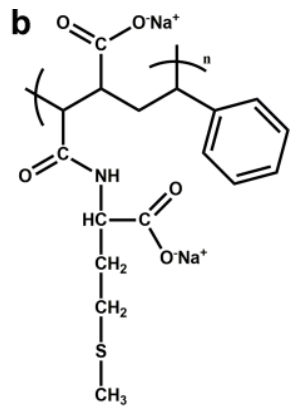

PSMA-Met<smiles>COC(=O)C(Cc1ccc(O)cc1)C(CC(C)c1ccccc1)C(=O)N[C@@H](CC(C)(C)C)C(=O)O[Na]</smiles>

PSMA-Tyr

Scheme 2. Polyelectrolyte structures: a) PSMA-GIn, b) PSMA-Met, and c) PSMA-Tyr

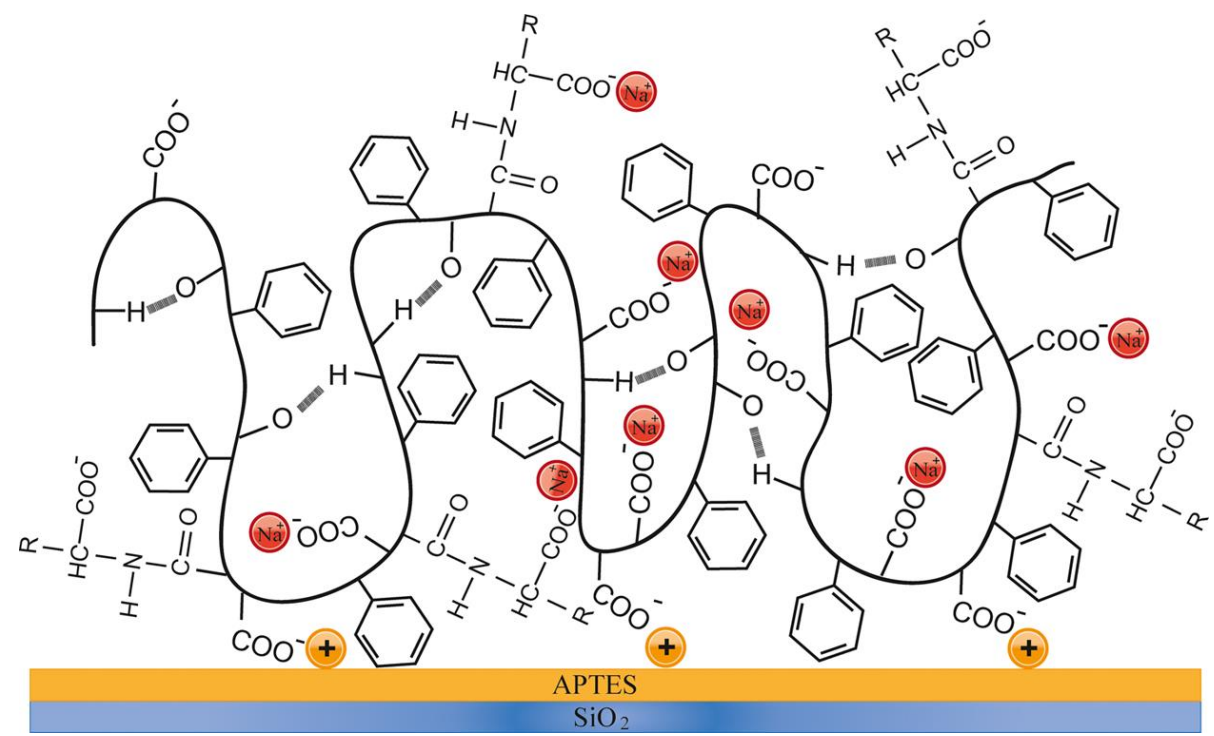

Scheme 3. Graphic Representation of Polyelectrolytes Adsorbed Onto Amino-Terminal Surfaces 

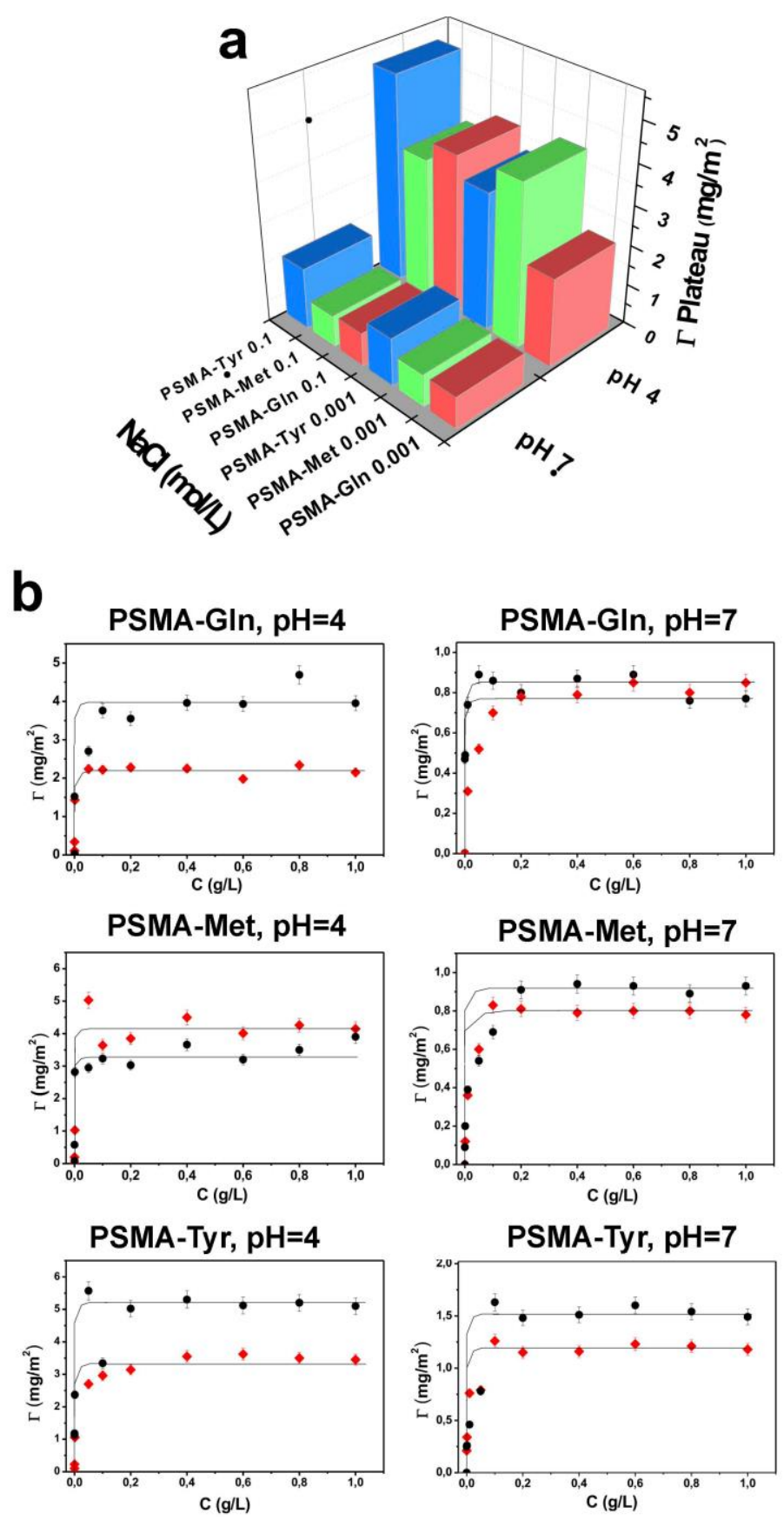

Figure 1. (a) Mean quantities of adsorbed polyelectrolytes in the plateau region (Gplateau) at different levels of $\mathrm{pH}$ and ionic strengths. (b) Adsorption isotherms obtained for PSMA-GIn, PSMA-Met and PSMA-Tyr on amino acid-terminated surface at $\mathrm{pH} 4.0$ and 7.0 under ionic strength of $0.1 \mathrm{M}$ and 0.001 $\mathrm{M} \mathrm{NaCl}$. 


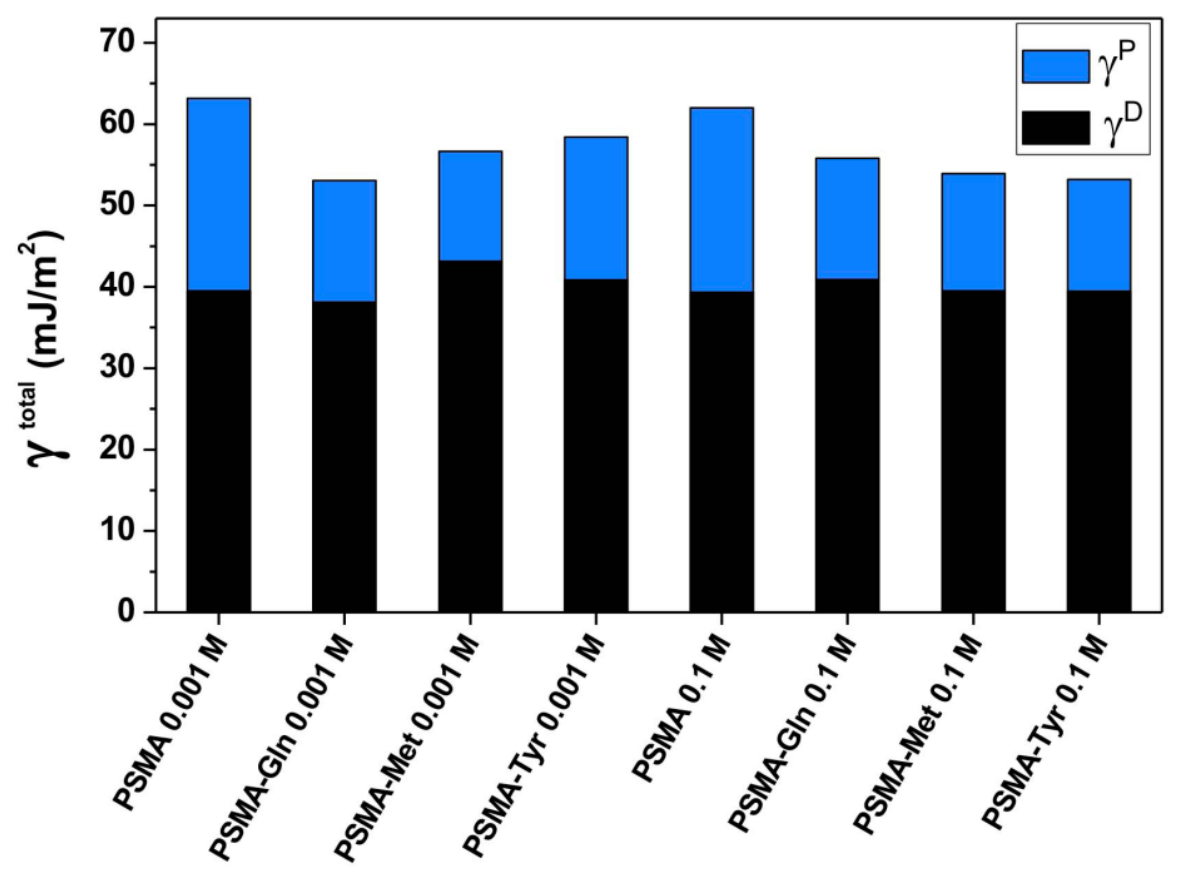

Figure 2. Surface energy $(\gamma)$ with the polar $(\gamma P)$ and dispersive components $(\gamma D)$ calculated for PSMA, PSMA-GIn, PSMA-Met and PSMA-Tyr films obtained at different ionic strengths 

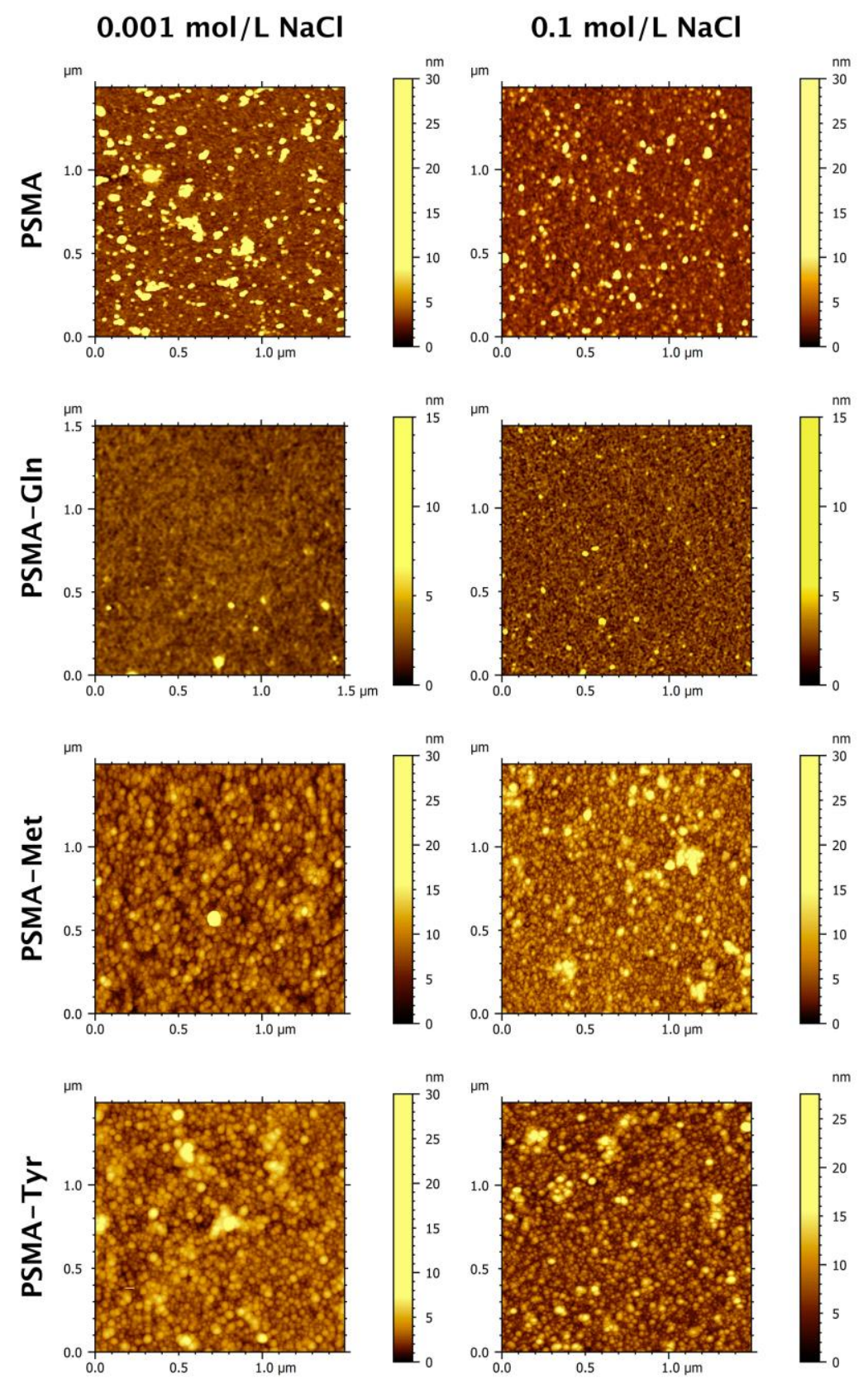

Figure 3. AFM images $(1.5 \mu \mathrm{m} \times 1.5 \mu \mathrm{m})$ of the polyelectrolytes adsorbed on a solid surface at ionic strength of 0.001 and $0.1 \mathrm{~mol} / \mathrm{L} \mathrm{NaCl}$, at $\mathrm{pH} 4.0$ 


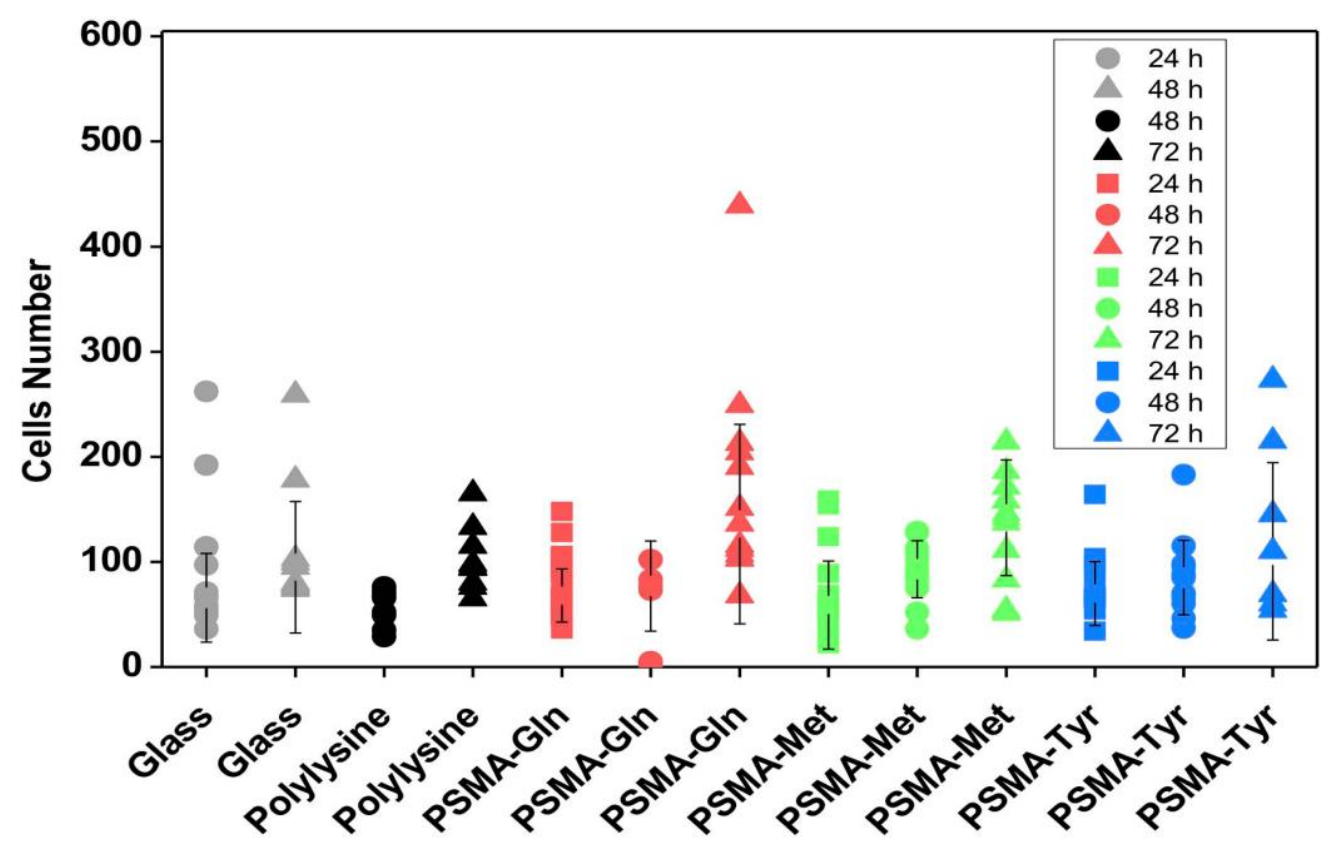

Figure 4. SH-SY5Y neuroblastoma cell proliferation is not impaired by different PSMA

modified substrates. 25,000 SH-SY5Y neuroblastoma cells were plated and cultured for 24, 48 and 72 hours on different substrates (glass, polylysine-coated glass, PSMA-GIn, PSMA-Met, PSMA-Tyr). Random fields were photographed under phase contrast microscopy and the cell number was determined in a double-blind fashion. Cell proliferation was not altered in response to the different substrates. 

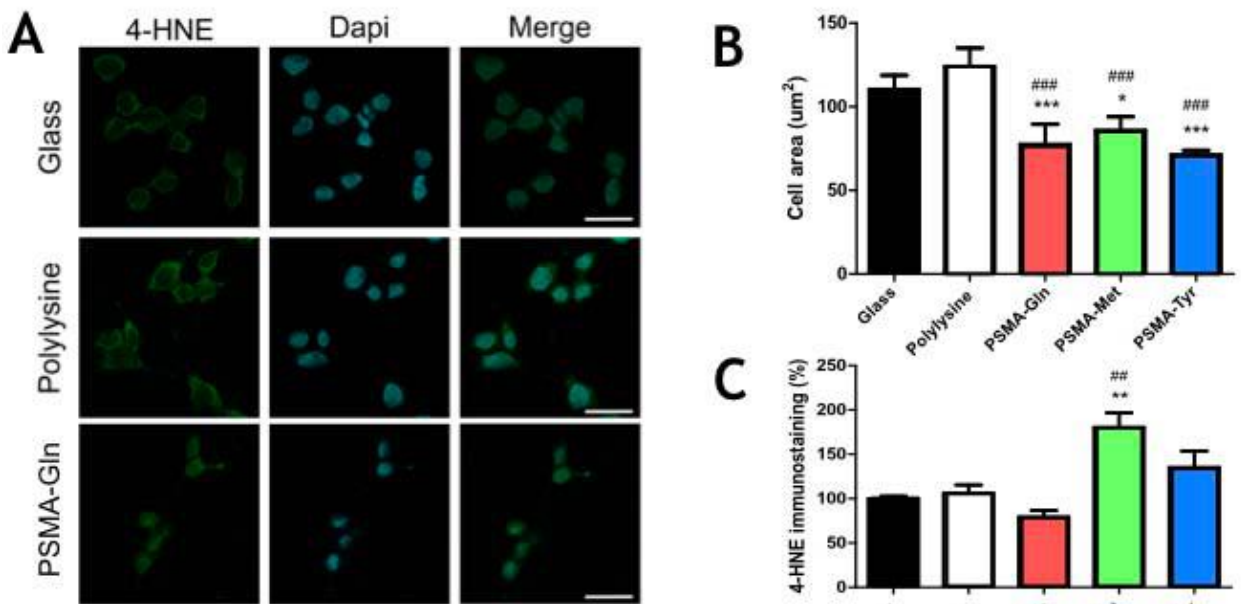

C
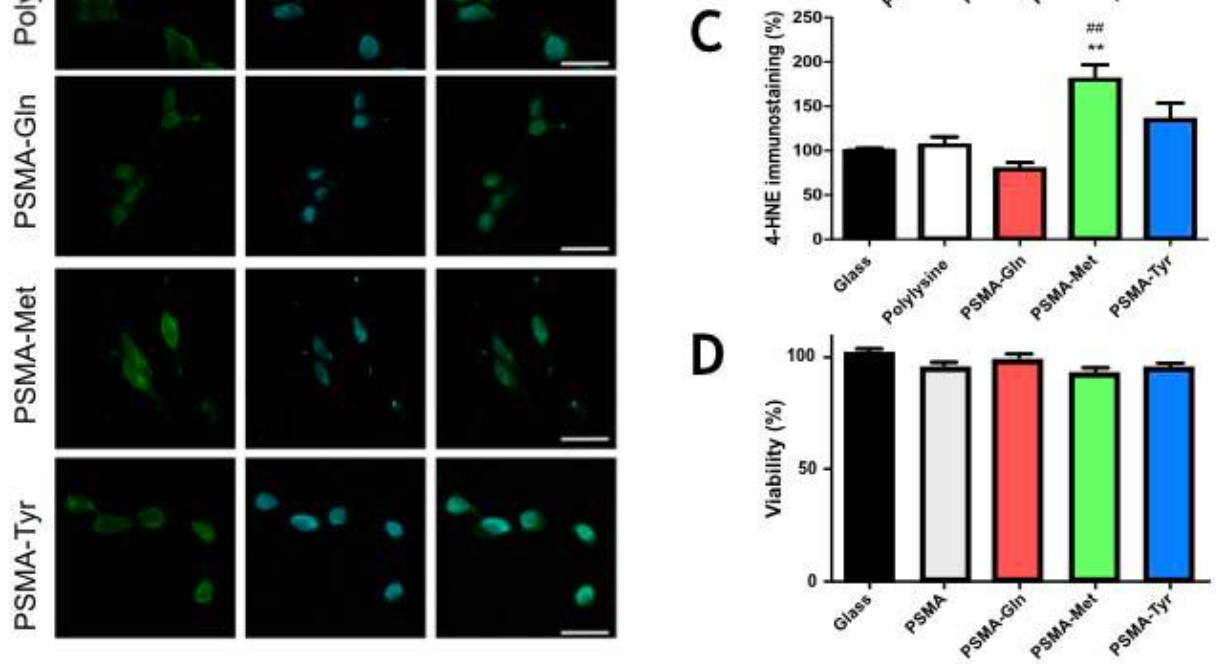

Figure 5. The area covered by SH-SY5Y cells on polyelectrolyte-modified substrates were reduced (B), but without altering cell viability. SH-SY5Y cells were plated on different substrates (A) and cultured for 24 hours ( $37^{\circ} \mathrm{C}, 5 \% \mathrm{CO}$ ). Cells were fixed and stained for immunofluorescence to determine the presence of 4-HNE, a membrane lipid peroxidation marker that indicates damage to cell membranes in response to experimental toxicity (C). Cells identified and counted by DAPI-nuclear staining ( $405 \mathrm{~nm}$, CYAN) were imaged for 4-HNE and found to be significantly fewer in number than the controls. Only cells plated on PSMA-Met showed a significant increase in lipid peroxidation, which indicates increased oxidative damage. Nevertheless, cell viability, as determined by MTT reduction, was not altered, even when cells were plated on plastic and treated with higher concentrations of polyelectrolytes in solution (D). 

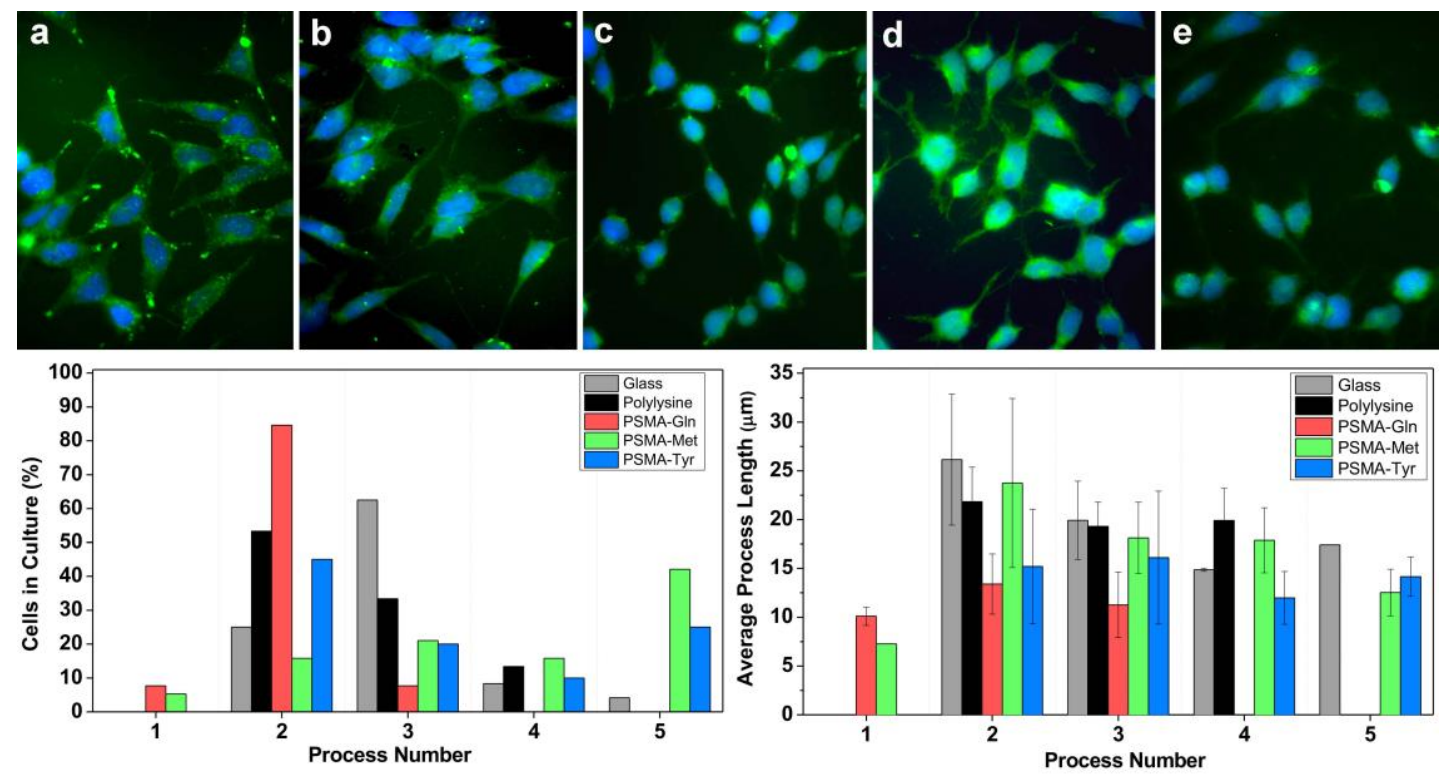

Figure 6. SH-SY5Y cultured on (a) glass, (b) polylysine, (c) PSMA-GIn, (d) PSMA-Met and (e) PSMA-Tyr. SH-SY5Y cells responded to PMSA-Met substrates with significant process extension and cell shape remodeling. Control cells a and $b$, glass and polylysine, respectively had fusiform (two processes) and pyramid (three process) shapes characteristic of undifferentiated neuroblastoma cells. Cells grown on PSMA-Met (d) had a stellate shape, with 5 or more processes, many of which extended over $5 \mu \mathrm{m}$ from the cell body. Cells grown on PSMA-GIn (c) present fewer and shorter processes.

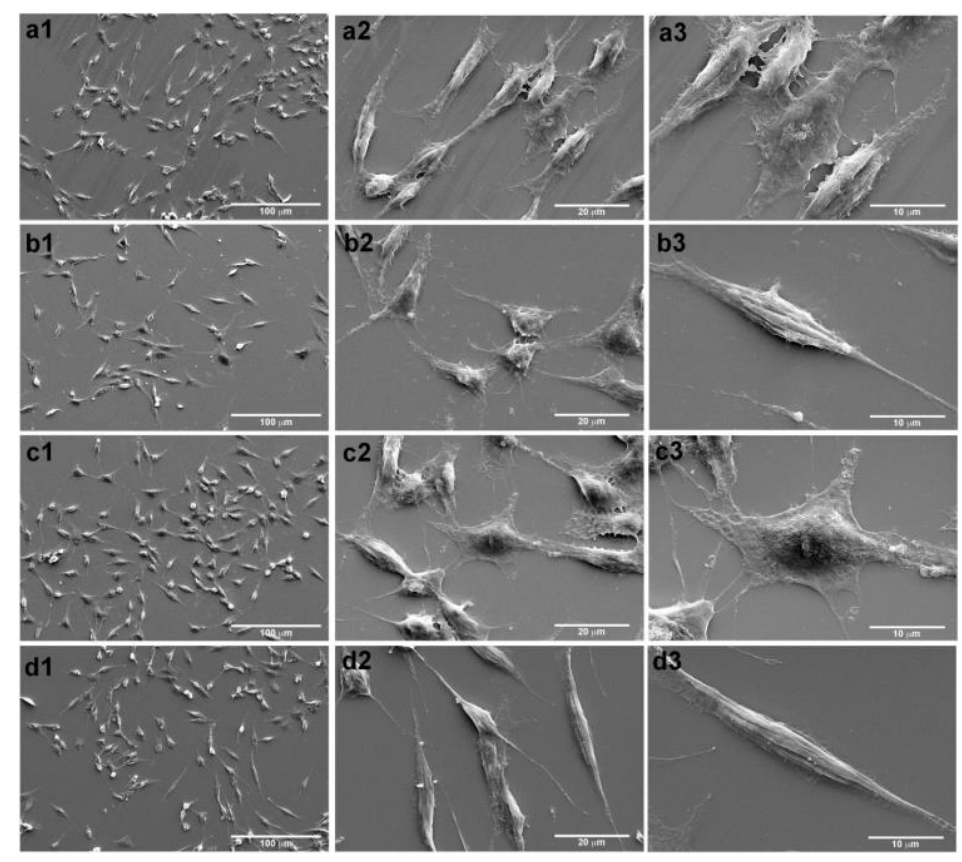

Figure 7. SEM images of SH-SY5Y cell cultures after $24 \mathrm{~h}$ on (a1, a2, a3) PMSA, (b1, b2, b3) PSMA-GIn, (c1, c2, c3) PMSA-Met and (d1, d2, d3) PMSA-Tyr 